\title{
On Military Hygiene
}

\section{F. S. B. François De Chaumont M.D., F.R.S.}

To cite this article: F. S. B. François De Chaumont M.D., F.R.S. (1883) On Military Hygiene, Royal United Services Institution. Journal, 27:122, 757-776, DOI: 10.1080/03071848309425434

To link to this article: http://dx.doi.org/10.1080/03071848309425434

\section{曲 Published online: 11 Sep 2009.}

Submit your article to this journal tra

Џll Article views: 2

Q View related articles $\sqsubset$ 
T. CRATFORD, Esq., M.D., Director-General, Army Medical Department, in the Chair.

\section{ON MILITARY HYGIENE.}

By F. S. B. Fraxicois de Caatyoxt, M.D., F.R.S., Professor of Military Ilygiene, Army Micdical School, Netley.

Ir is now thirteen years since. I land the honour of addressing this Institution on the subject of military hygicne, taking for sabjcctmatter the questions: 1st. The Ventilation of Barracks and Hospitals; and 2nd: The Ration of the Soldier. At that time only thirteen years had elapsed from the time of the sitting of the Royal Commission at the close of the Crimean War, an erent which proved to be the turning point in the health history of armics. WVe werc then (June, 1870) on the ere of the sererest European struggle since the Napolconic wars of the beginning of the century,-little as the fact mas suspected by many who ouglit to havo known better,and since that time there has licen a succession of mars of greater or less importance politically, but fraught with much instruction from a hygienic point of view. Those in which oar troops hare been directly engaged have been the Ashanti War of 1873, the Tars in South $\Delta$ frica, in Zululand and tho Transval, in 1877-80, the Affghan Campaigns of 1878-79, and the Egsptian Campaign of 1882. With a certain amount of similarity in tho circamstances, there were important individaal differences which gave a pecaliar cliaracter to each of these struggles. The first, the Ashanti War, was carricd on in one of the most inhealthy cren of tropical regions, and the losses by disease were in consequence greatly in excess of the losses by tho hand of the enemy, in spite of the rapidity with which tine campaign was accomplished. The South $\Lambda$ frican wars on the other hand were carried on in a sub-tropical climate, where the normal conditions are healthy, but where the exirgencies of war gave rise to considerable sickness. The Affghan wars were accomplished in a hill climate in the neighbourhood of the tropics; bat nnder circumstances of peculiarity and difficalty, aggrarated by the inrasion of tropical disease. The Egyptian Campaign was in a country- not exactly tropical, but in close proximity to tho hottest region of the earth; a country, too, of which our troops had a grave experience in former times as regards health, and of which they retained down to recent times an unhappy. reminiscence in the shape of ophthalmia. 
In the Army generally very considerable changes have taken place. It has, in the first place, become emphatically a young army, and it is gradually assuming a character wholly different from that in which those began their military career who, liko myself, have reached the half-century of life. In the second place the foreign service of the soldier is now almost entirely tropical or sub-tropical, the Colonies situated in the temperate zones providing mainly for their own defence. A third circamstance, which has an important bearing upon the health of the troops, is the change in the organization of the Medical Department, the abolition of the regimental system, and the substitation of the nuification system in its stead. I propose in the first place to consider briefly the general improvement which may be traccd in the condition of the soldier, as shown by the statistics of sickness, death, and invaliding in the general Returns at home and abroad; and afterwards to review shortly the results in the different campaigns above referred to. It is probably in the recollection of those who hare given attention to the sabject that the sickness and death-rate of our troops at every station was in former times most excessive, at all times exceeding those of civilians of the same ages, cren where the actual circumstances seemed in farour of the soldier. If we cast a glance at the older Returns wo shall find a condition of things that must excite surprise in any one becoming acquainted with them for the first time, and the simplicity of the means by which the improvement of the present day has been effected would astonish not less, did we not know how the plainest objects are often unnoted from their being actually too near for our vision, just as the most difficult names to find on a map are not those which are in the smallest letters, but those whose letters are exceptionally large and spread over a wide area. In the able abstract by SurgeonGeneral Balfour, F.R.S., which is to be found in the second rolume of the Army Medical Department Reports, that for 1860 , we have the following data:-

\begin{tabular}{|c|c|c|}
\hline & $\begin{array}{l}\text { Admissions } \\
\text { per } 1,000 .\end{array}$ & $\begin{array}{c}\text { Deaths } \\
\text { per } 1,000 .\end{array}$ \\
\hline $\begin{array}{c}\text { Guards (before 1837) } \\
\text { (after 1837) }\end{array}$ & $\ldots \ldots \ldots$ (no record) .. & $\begin{array}{l}21 \cdot 6 \\
20 \cdot 4\end{array}$ \\
\hline
\end{tabular}

In 1860 the following were the ratios :-

\begin{tabular}{|c|c|c|}
\hline & $\begin{array}{l}\text { Admiesions } \\
\text { per } 1,000 .\end{array}$ & $\begin{array}{c}\text { Deaths } \\
\text { per } 1,000 \text {. }\end{array}$ \\
\hline & $\begin{array}{l}737 \\
. \quad 904\end{array}$ & $\begin{array}{l}9 \cdot 48 \\
9 \cdot 95\end{array}$ \\
\hline
\end{tabular}

In 1870 the following were the ratios :-

\begin{tabular}{|c|c|}
\hline & $\begin{array}{l}\text { Admissions } \\
\text { per } 1,000 \text {. }\end{array}$ \\
\hline$\cdots \ldots$ & $\begin{array}{r}627 \\
\cdot \quad 707 \\
.\end{array}$ \\
\hline
\end{tabular}


In 1880 the ratios were:-

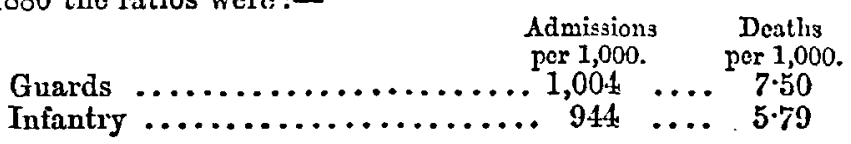

The total ratio for the Army at home for the ten Jears $1870-79$ was :-

$$
\text { Admissions ..... } 809 \quad \text { Deaths ..... 8. } 8.18
$$

And for 1880 :-

Admissions ...... 896 Deaths ...... 6.83

There has been thus a steadily diminishing rato of deaths, that is of serious disease. The rate of diminution has been :-

Rate of 1860 was 44 per cent. less than that before 1854 .

" $1870 " 26 \quad " 36 \quad " \quad$ " 1880 of 1860.

The general death-rate of the Army at home for the ten years 1870-79 was 56 per cent. below that before 1854, and the rate for 1880 was 62 per cent. below it.

If we now look at the classes of disease which have been thus diminished, we shall find that they are especially those which have been distinctly recognized as preventible by sanitarians, viz., destructire diseases of the lungs and typhoid (or enteric) fever. With regard to the former, we find that the ratio of death from destructive lung disease (included under the head of phthisis or consumption) was, in the period $1830-36,7 \cdot 83$ per 1,000 , and in $1837-46,7.89$, or practically the same, showing no tendency to diminish; and those numbers did not include the deaths from inflammatory disease of the lungs. Thus in the jears 1830-36 there were annually in the Foot Guards 10.8 deaths per 1,000 from "phthisis, bat 3.3 also from other lung diseases, making a total of $14 \cdot 1$. Now the total deaths from all disenses in 1880 were only 6.83 per 1,000 , or 12 per cent. less than the consumption deaths alone thirty years ago, and 37 per cent. less than the consumption rate of the Foot Guards. The total consumption death-rate of the Army in 1880 was under 2 per 1,000 , or 75 per cent. less than the pre-Crimean rate. This eminent improvement has been conclusively proved to be the result of the improved condition of ventilation in the soldiers' sleeping rooms, which has been gradually effected since 1858. But that it is not yet sufficient we know from two sources. In the first place, the amount of air contemplated by the Barrack Commissioners is much smaller than what is now recognized as necessary for the best health and efficiency. But the Commissioners showed wisdom in restricting themselves to requirements which there was a reasonable hope of carrying out, rather than in insisting upon conditions which would certainly at the time have been looked upon as chimerical. The amount contemplated and now giren is 1,200 cubic feet per head per hour; but the amount desired in the present 
day is just threo times that, 3,600 cubic feet, or one cubic foot per second. In the second place, if we comparo the phthisis death-rate of the Army with that of civil life, we find it to be still in excess. For that purpose we must take not. only the death-rate, but also the ratio of invaliding, for by this the Army gets rid of cases which would otherwise provo fatal, but which go in reality to swell the denth-rate innong civilians. Of course the effect apon the ciril death-rate is hardly appreciable, but the difference that their removal makes on the Army rates is very.considerable. Thas in $1880,4 \cdot 15$ per 1,000 were invalided for this class of disease, and this added to 1.98 of deaths gires a total rate of 6.13 per 1,000 lost to the Army from one class of disease. If now we émpare theso figures with the ciril Returns, we find that the total deaths on the general male population is only two-thirds of this, that London shows only 75 per cent. of it, and that the worst districts of England (excluding hospitals) show only 81 per cont. of it, or less than five-sizths of the Army rate. The healthiest. districts of England, on the other hand, show only 1.96 per 1,000, or. 68 per cent. less than the Army xate. Now, when wo consider that the Army is a group of selected lires, and that the consumptivo recruits who are rejected fall back into the ranks of civil life, it is clear that there is still something that keeps up this serious drain upon the Service. This something, I have no hesitation in saying, is the still imperfectly ventilated barrack room. It is just a quarter of a century since the grent change was begun which has been so happily fruitful in saring to the State and health to the soldier; but mach still remains to be done. I think it is now timo to revise again the soldier's accommodation and to improve it so far as to bring his condition somewhat more abreast of modern sanitary science. The thing of conrse could be easily done, for it is merely a question of money, but I am afraid the getting of the money will prove the difficulty. The improvement of barrack rooms is less striking than a battle or a brilliant campaign, but its good effects would be more certain and lasting, and the cost not greater. Could wo double the space the soldier has in barracks, even without increasing the means of ventilation, an enormons beuefit would be obtained, but if wo could do both, as we should certainly do if the opportunity were given, there is no reason why the lass from phthisis should be moro than in the healthiest district in England. This would be a saving of about 350 men per annum in the lome Army alone, and if we take the nsual estimate of the ralue of a soldier at $100 l$. this would be a saving per annum of $35,000 l$. This capitalized at only twenty jears' purchaso would bo $700,000 l$., which would go a long way in proriding the sdditional accommodation desired. But we should be doing moro than this, for wo should bo thus increasing the number of healthy males destined to be fathers of healthy progeny, and the Army would thus do its part in gradually stamping out consumption in one midst.

Another important group of diseases is the so-called zymotic or febrile group. Among these we find, as the most important in this constry, typhus ferer, typhoid (or enteric) fever, and small-pox, with 
cholera which is only an occasional invader. Of these wo may say that typhus has ceased in times of peace to be a matter of anxiety. Tro conditions must be present together to give rise to or favour the propagation of this disease, viz., crowding and destitution.. Neither of these is now likely to be present among our soldiers, therefore the origination of typhus among them is rendered practically impossible. Eut the disease onco begun is excecdingly contagious, and can be easily communicated from person to person, so that in a serions epidemic no class is free from the danger. The general improrement, howerer, in the well-being of the poorer classes has to a large extent abolished the causes of typhus in late years, and the health of the soldier has reaped the benefit. In time of war it is a disease to be always feared. 'It cansed immense loss to our troops in the close of the last and the beginning of the present century; it sererely scourged the French Army during the retreat from Leipzig; it was one of our direst foes in the Crimea, and it committed great rarages on both sides during the last Russo-Turkish War. It has sometimes been remarked as a curious fact that there was no typhus to speak of during the siege of Metz, bat it need not be wondered at, for the compressiun was not ncarly so great as has been the case in other instances, and there was; no true destitation; facts in their result which ought to be taken into consideration in estimating the wisdom or good faith shown in the surrender of that important position, a surrender which hopelessly compromised the fortunes of the French in that terrible confiict.

As regards small-pox, the disease has been practically stamped out in the Army at home. During 1880 there were only three cases of the disease in 84,000 men, and the ratio for years back has been exceedingly small, although from the inconvenient form of the Returns it is difficult to state the exact number of cases, mixed up as they are with other eruptive disorders. Wo may, however, confidently say that the vaccination and re-raccination of the troops has been so perfectly performed as to reduce the chance of their taking small-pox to a minimum. Among our foreign stations we had similarly small numbers in 1880, the only cases occurring being in Gibraltar, Malta, China, and India, 11 in all and 2 deaths; or a total ratio at home and abroad of less than 9 cases per 100,000, and little over 1 death per 100,000 of strength.

Cholera.-This formidable disease is endemic only in the Delta of the Ganges and Brahmaputra, and perhaps also in that of the Irrawaddy. Its causes are still obscure, as are also to somo extent the modes of its spread. We know, however; that it does spread from time to time begond its usual focus, and that no conutry is safe from its invasion. We have good proof that hygienic measures, such as the provision of pure water in plenty, care about the removal of excreta and general cleanliness, are powerful means of combating this dreadful enemy. That can be done, when those hygienic means aro carried out uniformly and well in a community, may be seen by the diminution of cholera deaths in the Army at home in the last epidemic -that of 1866. In former epidemics the troops had suffered severely 
like the rest of the community, but in 1866 there were only 13 deaths out of 70,000 men, and only 17 cases of the disease; which is a very fatal one; the usual mortality being about 2 out of 3 (or 20 out of 30); but in the above group it was even more, $2 \cdot 3$ out of 3 (or 23 out of 30 ). The above death-rate was little over one-third of the general cholera death-rate of the kingdom in that year. Since that time so much has been done, both in civil and military commanities, to improve the sewerage and water supply, that I think it is not too much to say, that even if cholera did reach our shores, it would in ail probability fail to establish a foothold.

The remaining group of ferers, namely, enteric (or typhoid) fever, is of much more importance to us than any of the former. Cholera is a mere casual visitor, but t5phoid is always with us; typhus arises under conditions that are quickly recognized, and may be rapidly altered, bat typhoid is a disease of insidious cha. racter, the cunse of which often lurks unsuspected; against smallpox we have a safe defence and sure prevention, bat we have none such against typhoid. This disease kills in the United Kingdom some 10,000 to 11,000 every year, the total number being about 108,000 for the first ten years (1869-78) after the disease was separated from other fevers in the Registrar-General's Returns. It is a disease which is peculiarly a diseaso of bnd sanitation, arising from either air or water being poisoned by the omanations from excreta, undergoing decomposition in confined spaces. It has often shown itself more a disease of the rich than of the poor, and this for troo reasons, it is believed. Firstly, because water-closets and such conveniences have been more generally within the houses of the better classes, whilst the poorer more generally resorted to places outside. Sewer air therefore would be less likely in the latter case to get in from ill-ventilated and untrapped drains. Sinks also, and fixed baths are other channels of access for sewer air. The second reason has been thought to be (although this is less certain) the mode of living of the wcalthier classes, especially the use of richer and more plentiful food. There is, howerer, no reason for any one taking typhoid fever, if proper precautions be adopted; drain and soil pipes may be properly trapped and rentilated, sinks and bath-wastes may deliver harmlessly in the open air; and the water supply may be effectually protected from all contamination. In former days we lost a number of men from ferer, but this has been gradually diminished. In ten years, 1837-46, there were 620 admissions, and 17 deaths per 10,000 of strength, for continued ferer; in the eight years ending 1867 , there were only 220 admissions, and 5 deaths per 10,000 ; in 1871 the ratios were only 9.2 and 2.5 respectively. In the four years ending 1875 , the deaths were 3.7 per 10,000 ; in the five years ending 1880 , the deaths were 3 per 10,000 , and in $1880,2 \cdot 6$. If we compare this with the condition of things in civil life, wo find that the death-rate, among male adults of the same ages as soldiers, is 10 per 10,000, or nearly four times the Army death-rate. If we look again at the proportion that the typhoid deaths bear to the total deaths, ro find that in the Army they are only 4 per cent. of all deaths, whilst in civil life, at the same ages, they aro 
9.6 per cent., or nearly two and a-half times as great. This result, following as it does on the marked improvements which have been carried out in the sewerage and water-supply of barracks at home, is a strong corroboration of the view which connects typhoid fever with imperfect sewerage arrangements and contaminated water.

Of the other diseases which canse mortality among troops at home, there is one group that attracts attention, and that is, the disenses of the heart and great vessels. This question has been carcfully investigated by rarious medical officers, but particularly by InspectorGeneral Lawson (retired), by Professor Maclean, of the Army. Medical School, by Surgeon-Major Miyers, of the Scots Guards, and by the late Professor Parkes. It is certainly a startling thing to find eren now that this class of disenses stands second in the list of mortality among soldiers, and causes more than one-serenth of all deaths. Dr. Lawson calculated some jears ago that aortic ancurism (a sack-like dilatation to the great artery of the body) was eleven times more frequent among soldiers than among civilians. Mr. Myers showed that the deaths and invaliding from heart disease in the Foot Guards as compared with those in the Metropolitan Police were as follows:-

$$
\begin{array}{lcccc} 
& & \begin{array}{c}
\text { Died } \\
\text { per } 1,000 .
\end{array} & & \text { Inralided } \\
\text { per } 1,000 . & & \\
\text { Foot Guards } & \ldots . . & 0 \cdot 80 & \ldots . & 3 \cdot 20 \\
\text { Police } & \ldots . . & 0.29 & \ldots . & 1 \cdot 37
\end{array}
$$

They were also greater in the Army than in the Navy to the extent of 3.5 per cent. of deaths and 50 per cent. of invaliding. Compared with tho general population (males between 15 and 44 jears of age), Dr. Lawson shorred that the deaths from heart discase were 60 per. cent. more numerous in the Army thar in civil life. In 1880 there died of diseases of the heart and vessels in the Army at home 81 soldiers, there were invalided and discharged from the Service 390 , and thero were constantly sick 115, so that there were 586 men whose service was lost to the State, or about two-thirds of a battalion. It has further been shown that although the loss is large in all arms it varies with the particular arm. Thas, in the infantry of the line the total loss by deaths is $1 \cdot 11$ per 1,000 (1867-71, for since that time details are wanting); in the Foot Guards, 1.36 ; in the cavalrs, 1.44 ; and in the artillery, $2 \cdot 25$ per 1,000 . Or, taking the infantry of the line as unity, we have 25 per cent. more in the Foot Guards, 30 per cent. more in the cavalry, and 105 per cent. more in the artillery. Considering that the ratio in the infantry is more than double that of civil life, there must be some sufficient cause for this remarkable amount of disease. In civil life rheumatic ferer and disease of the kidneys are the tiro most common causes of heart disease, but neither of these can operate much in the Army. Besides, Dr. Parkes showed that, of the young soldiers invalided in the two first years of service, diseases of the circulation formed 14.23 per cent. of all causes of invaliding. Neither syphilis, nor intemperance, nor excessive smoking, although these might be contributory causes, could account sufficiently for the condition of things obserred. After au inquiry of an exhaustive 
character it was narrowed down to one set of causes, viz., tho work the soldier had to do, and tho unfarourable circumstances in which ho had to do it. All who are conversant with the subject will admit that the life of the soldier in time of peace is by no means a hard one, that is, he works on the average less than the ordinary labourer or artizan of the classes from which he is taken. Thus, if we take the arerage daily work of a labourer at a little over 300 foot-tons, the soldier does not do more than abont two-thirds to three-fourths of this; or, say, a labourer or artizan may do 2,000 foot-tons a week, whilst a soldier probably does 1,400 to 1,500 . Indeed his rations, if he depended entirely on them, would not provide sufficient energy for more than this. But in the work of the soldier we have an element which does not always enter into the work of the artizan or labourer, and that is, the increased velocity of work producing strain. The effects of strain in mechanics is well known to all engineers, and the human frame suffers much in the same way as beams, girders, and mechanical engines do. Men who suffer most in this are the artillery, whose drill with their special arm calls for very sndden and violent exertion; next come the cavalry, who are also called upon for sudden exertion, althongh in a less degree; and, Jastly, the infantry, who have to undergo rapid work, such as in doubling, which tells upon the men. Now this is exactly the order in which the mortality from heart and ressel diseases shows itself-the artillery being highest and the infantry lowest. As those exertions, however, are part of the work of the soldier they cannot be altogether aroided, but the conditions under which they aro done may certainly be improved, and the necessary evils lessened. Now, formerly tho soldier performed his work under very adverse circumstances, particularly in the matter of lis accoutrements and his clothing. The effects of the old knapsack and cross-belts are too well known to requiro repetition here, and much, if not quite all, of the objections have been removed by tho introduction of the new. equipments. But it is not the same with the clothing, which is still too tight across the chest, at the neck, and round the armpits, tending not only to impede movements, but to distress the man. No civilian would consent to work under the conditions imposed npon the soldier, whilst the sailor of the Royal Nary, who is exposed to at least as hard and sudden work, suffers in a much less degree than his Army brother. Looking to the statistics of successive periods wo find that in 1867-71 (5 years) the deaths from diseases of the circulation were'in the Army 1.462 per 1,000, and that ther formed 16.71 per cent. of all deaths ; in 9 sears, 1872-80, the deaths were $1 \cdot 17$ per 1,000 , and $14 \cdot 8$ per cent. of all deaths; and in the last three years of this period, 1878-80, the deaths were 0.65 per 1,000 , and $10^{\circ} 4$ per cent. of all deaths. In 1880 tho deaths wero 0.52 per 1,000 , and 9.1 of all deaths. We have here a progressivo improvement, no doubt due in large measure to the better arrangemonts for the carriage of the necessaries. Bnt when we consider that tho loss in the Army is still above that in civil life, and that the soldier's life is a selected one, no recruit being taken who shows signs of disease in the heart and ressels, it is obrious that much yet remains 
to be done. The percentage of all deaths in civil life, which the circulation deaths show at all ages, is $6 \frac{1}{4}$, between the nges of 15 and 35 it is $6 \frac{1}{2}$, between 15 and $45,8 \frac{1}{2}$, whilst between 15 and 25 , the ages to which our Army has been tending, it is under $5 \frac{1}{2}$. Now, as we have already seen the percentage in the Army for three years, 1878-80, was $10 \cdot 4$, and in 1880 alone still $\cdot 9 \cdot 1$. Again, those discases are in the Army second in the scale of mortality, whereas they are only sixth in the list of canses of total deaths in civil life at corresponding ages. Although several causes may combine to produce this grave difference, I am convinced that it is the tightness of the clothing which is still hampering the soldier, especially in his more rapid morements. It is much to be desired that the idea of smartness, which is still associated with a degree of tightness and stiffness of dress, should be got rid of, and that our men should bo clothed more in accordance with the work they have to do. There is no reason why the clothing should not be made becoming, and we may instance the Navy; no dress gives a more manly and even graceful appearance than that of a sailor, who is equipped for work primarily; besides, the eye would soon accustom itself to a change really useful, and in the words of Vaidy, "La tenuo dans laquelle le militairo est pret à marcher à l'ennemi est toujours belle."

Let me now eall attention to some of the changes which have taken place in the statisties of the Army in foreign stations, in some of which changes even more startling than those at home have shown themselves. It is of course impossible to do more than glance briefly at a few, and I may select as typical examples the Jiediterranean stations, the West Indies, and onr Eastern Empire. The redistribution of our Army has greatly diminished the garrisons in many places abroad, but we still retain a considerable number at Mralta and Gibraltar, and a largo force in India.

Iralta and Gibraltar, from their situations and equable climates, ought to be healthy, and in former times they were really healthier than home statiois werc. Thus in 1837-56 the death-rate at Gibraltar was only 12.9 per 1,000 , or one-third less than that of the Army at lome; before 1837 it was not very different from that of the Foot Guards in London. Malta was less healthy than Gibraltar in the second period, but not more unhealthy than the average of home stations, and less unhealthy than London, as represented by the Guards. In 1860 the deaths at Gibraitar were $12 \cdot 4$ per 1,000 , but at that time none of the subsequent improvements had been carried out. In 1861-70, however, the ratio was only $8 \cdot 54$, and the arerage of the ten years 1870-79 was 6.98 . The ratio for 1880 was only 4.24 , of which 3.57 only were from disease. In like manner in Mralta the deaths have been reduced to one-half of the former rates, but they are still too high, as they are 20 per cent. higher than at home for tho ten years 1870-79, and 50 per cent. higher than that for 1880 . They also exceed those of Gibraltar by 40 and 135 per cent. respectively. What are the diseases that causo this difference? Chielly continuedthat is, enteric (or typhoid) fever. In other rords, the drainage of both places is at fault, but more especially that of Malta. But the 
sickness at Malta is also too great, being 7 or 8 per cent. above that at home and 20 per cent. above that at Gibraltar. Were it not that a Contagious Diseases Act is in force at Malta, and only imperfectly carried out at Gibraltar, the difference would be more marked still. But it is in the class of fevers that the difference shows itself, the admissions at Mralta being 50 per cent. greater than at Gibraltar, and the constantly sick 15 per cent. more. This is dne to the existence of a peculiar form of disease, known variously as Malta fercr, rock ferer, Mediterranean fever, \&c., which prevails throughout the Mediterranean shores. It is a painful and protracted disease, as I can rouch for from personal experience, but not a fatal one. It prevails much more at Malta than at Gibraltar, and the canse appears to be defective sewerage. It seems to be a blood poisoning, arising from the soil being more or less saturated with fæcal matter, probably resulting from the practice of cutting drain-channels through the porous rock, instead of laying down impervious pipes. Now the rock at Malta is excecdingly absorbent, whereas that at Gibraltar, being of mountain limestone, is much less so, hence possibly one cause of difference. This defect also tends to the production of ophthalmin; diseases of the eyes are twice as prevalent at Mralta as at Gibmltar. All this points to the necessity of remodelling the drainage of Valetta and the adjoining towns and forts.

Turning to the West Indies wo find now but small garrisons in the present day compared with those which formerly occupied them; but, such as they are, they present a marrellously improved condition of health upon their state in former times. In 1817-36 the death-rate of white troops in the TVindward or Leeward command wns 81.5 per 1,000 , and in Jamaica 128. In 1837-55 it ras 62.5 and 60.8 respectively. In the ten years $1870-79$ it was $10 \cdot 99$, and in 1880 only 8.68 , or onetenth of the former rate in the WVindward and Lecward command, and only one-fifteenth of the rate in Jamaica. What were the causes of the former inordinate deatlh-rate and of the great change since? Simply bad hygienic conditions in the one case and their remoral in the other, as in all similar cases. In old days the food was bad, the meat nearly always ealt, and the use of regetables was discournged; the water was generally bad, but rum was only too plentiful. The barracks were totally unventilated, the men slept in hammocks toncling ench other, there being only 23 inches of width per man allowed, while each had only $22 \frac{1}{2}$ square fect of floor-space and 250 cubic fect of total space. And this is the description of the best barrack (that at. Tobago) in that part of the tropics! No wonder men died at the rate of 16 per cent. in ordinars years and at 25 per cent. in epidemic times. Now all has been changed-food, water, barracks, all have been improved, and we see the result. But there is ton much ferer and some other diseases, which plainly show that there is still room for improvement.

But our most important possesssion is the great Empire of India, which absorbs one-third of our regular forces eren in times of peace. Here we find changes not less remarkable, and of course on a much greater scale. The evidence collected by the Royal Commission 
nearly a quarter of a century ago is a mine of information on this important subject. In the first half of this century, in fact down to the MIutiny, the general death-rate of European troops in that country was about 69 per 1,000 . In 1812-16 it was $96 \cdot 5$ per 1,000 in Bengal, and in 1819-20, 80 in Bombay. The same causes wero found operating, not onls dietetic errors and intemperance, not merely heat and malaria, but bad barrack nccommodation, $a$ want of proper ventilation, impure water, imperfect removal of excreta, \&c. Once these were recognized, steps were taken for their removal, with the usual result -an immediate amelioration of conditions. In 1860-69 the mortality in Bengal was only $31 \cdot 27$, and in 1870-79 only $20 \cdot 17$. In Madras it was 22.5 in 1860-69, and nnder 19 in the succeeding decade, and in Bombay it went down to 16.37 , or considerably under the home rate before the Crimean War. In 1880 the Mradras rate was only 10.51 , just one-half of the former rate of the Guards in London. This shows to what a low rate the mortality may be brought, and indeed there is no valid reason why this should not be the normal instead of an exceptional rate. As it is, at present we have great fluctuations; thus in Bengal the average of the ten years was little over 20 , but the rate for 1879 was 32 , whilst that for 1877 was only $12 \cdot 5$, or a difference (taking the latter as unity) of more than 150 per cent. The other Presidencies are not liable to quite such marked fluctuation, but still they are considerable. The causes in Bengal are several, bnt one of the chief is cholera, which finds its home in the eastern division of it. It is always present there more or less, but every now and then it becomes exacerbated, bursts its usual bounds and spreads into the remoter parts of the province. If we remove the cholera deaths we find that the death-rato is much more uniform and more like that of the rest of India. At the same time the general death-rate is too high, and there is no doubt it can be reduced. There is too much continued forer, that is typhoid, and this is distinctly preventible; there is also too much paroxysmal fever, avoidable by better selection of stations; too much phthisis, aroidable by better barrack accommodation and improred rentilation. The sickness is too large, as well as the deathrate, being trice the rates at home. There is one point that may well be insisted upon, and that is the impradence of the regulations which confined men to barracks during the most of the day. The motive was good, viz., to keep them out of the sun, but the remedy was worse than the disease, for it compelled them to breatho a foul and tainted atmosphere, which they had again to breathe at night; and it made their lives irksome and monotonous to a degree that was intolerable. NIen may be trusted to keep out of the sun without being subjected to such a terrible and destructive ordenl. A proof of what has been said may be found in the fact that those who are lcast confined to the house in India enjoy the best health. Officers are not so restrained, and their health is better than that of the men; civil servants bave to do much of their work in the open air in very hot weather, and they are more healthy still; and planters. who are necessarily active during the day, are the healthiest of all. 'The Medical Officers on the Madras establishment (as shown by the statisties of the Medical Fund) die at

vor. XXXII. 
a less rate than those of the British Army, taking all stations together. temperate as well as tropical. In the words of Miss Nightingale, men may.live and not die.in India; but the condition is that they shall livo hygienically, and surely it is the business of the Government thrit, in the case-of-troops, who are not free to chcose their ray of life, no obstacle shall be placed to prevent the best and most hygienic form of life. I feel convinced that, if the rules of hygiene were properly carried ont, the death-rate in India need differ very little from what it is at home, although men will alrays be handicapped to some extent by excessive heat and malarious influences. But active lires will combat the former, and improved drainage and means of agriculture the latter, whilst wo may hope that it is not chimerical to believe that a time will come when cholera will be merely an historical curiosity. In. the meantime it is possible eren now to protect the joung soldier from typhoid forer, cholera, and dysentery, in which case he is actually better off as regards health when in India than he is in barracks at home.

We may now turn shortly to the question of hygiene in time of war. If hygiene is important in time of peace, it is infinitely moro so in time of war. There is nothing which so impairs and ultimately paralyzes a force as disease; no loss that the enemy can inflict in battle being at all comparable to it. This has been recognized by all great commanders. It was preventible disease that caused the collapse at. Walcheren, that more than once threatened the armies in the Peninsula, and that produced our disnsters in the Crimea. In the Walcheren Campaign there was hardly any fighting; but tho position was so badly chosen, without ang reference whatsoever to medical opinion, that the fate of the expedition was sealed almost before a shot was fired. In three months 2,000 men perished and 10,000 were attacked with disease, which the majority never afterwards got.rid of. One-fourth of the entire force perished $(8,000$ deaths), and the greater part of the remainder filled the hospitals for many a long. diay.

The history of the Crimean Campaign is well known. By.a com. bination of circumstances, not unlike that - of Walcheren, the first army perished, some 16,000 men dying of disease alone, the most of them during the first. winter of the campaign. .Unlike the Walcheren story, however, the war lasted long enough to enable a recovery to bo made, and wo had in the second year a condition of health greatly superior to that of the troops at home, and in the spring of 1856 there was hardly a man who could not have marched against the enemy, the number of sick boing in many cases nnder 1 per cent., and these tritling cases, whilst in some battalions there were practically no sick at all.

The diseases which were most fatal at Walcheren were paroxysmal fevers, typhus (and probably typhoid), and dysentery, aggravated by scurvy. These were the result of malarious site, bad water, bad ratious, crowding, and inaction. In the Crimen the diseases were typhus and typhoid fevers, diarrhœa, dysentery, aggravated by scarrs, and at certain times cholera. These were due to the same 
cnuses, except the malarious site, which, however, operated on the army in Bulgaria. My colleague, Professor Aitken, has also drawn attention to the marked.influence which previous exposure of troops has in diminishing their power of resistance. In tho Walcheren Campaign a large number of men had already gone through exhaust. ing service in the preceding years, and in the Crimean TVar those men who formed part of the Bulgarian Army suffered to a greater extent than the men who went to the Crimea direct.

Putting on one side the Indian Mrutiny, in which the circumstances were peculiar, the next war in which our troops were engaged was that in the north of China in 1860. This was of course a small affair so far as the number of troops was concerned. The total sickness and mortality were at the rates of 2,049 admissions per 1,000 , and 53.98 deaths, including both North and South China. In the North China force alone the rates were, from May to July, 1620.7 admissions and 22.55 deaths, and from August to November 15, 1823.8 admissions and 65.54 deaths per 1,000 of strength. Fevers, dysentery, diarrhœe, and cholera constituted two-thirds of the deaths, but if they be compared with the preceding years of Chinese experience it will be found that they differed but little, except for the better, from the previous ratios; for in 1859 the admissions were $2,783 \cdot 2$ per 1,000 , and the deaths.59:35, a marked proof of the excellent way in which the hygiene of the Army was attended to.

Our next small war was that of Abyssinia 1867-68. The ratio of admissions was anly $891 \cdot 6$, and of deaths $36 \cdot 14$ per 1,000 of strength. There was nobody killed in action, but 9.37 died from accidents, so that the actual deaths from sickness were only $26 \cdot 77$, of which 47 per cent. died from dysentery and diarrhea, less than 10 per cent. from fever, there being but one death from continued, that is (probably) typhoid fever. This is an excellent example of good hygieno in the field.

In the Ashanti Campaign of 1873 the amonnt of sickness was small if we consider the nature of the country in which the war was waged. This was due to the facts that a suitable season was selected, that the war was carried out with great skill and rapidity, and that the arrangements for the hygiene of the troops were admirably planned and well carried out. As it was, the sickness amounted to about 1,700 admissions, and the deaths to 31 per 1,000 of strength (per annum). 'Tho Officers in this campaign actually suffered more than the men. The chief diseases were fevers, chiefly remittent, sunstroke, and heat apoplexy, and dysentery and diarrhœe ; but the comparatively small mortality, in an expedition campaigning in one of the most pestilential countries in the world, is a very remarkable circumstance. Now, in all these three campaigns-in China, Abyssinia, and Ashanti - the influence and advice of the Medical Department were allowed very great weight, and as in each case the principal medical Offieer of tho expedition was a man of great ability and long experience, tho Army profited accordingly.

I now come to the most recent operations. Although the campaigns in Affghanistan and South Africa are both interesting and full of $3 \div 2$ 
instruction, I should not have time to dwell upon them within the limits of the present lecture. I shall, therefore, refer briefly to the late war in Egypt only. The events of it are fresh in the memory of all, the genins with which it was planned and the consummate skill with which it was carried out. It was waged in the hot season of a sub-tropical region, under circumstances which placed great strain upon every part of the force. Yet the hygienic results are extremely good. Out of a force of 13,013 arerage strength there were 7,590 ndmissions to hospital in a period of 87 days, of which 671 were from wounds and injuries, lenving a ratio of admissions for disease of 530.2 per 1,000 . If this be expanded into a ratio per annum it becomes 2,222 . Of these about 10 per cent. were constitutional and venereal disease, not peculiar to campaigns, so that the total amount may bo reckoned at 2,000 per 1,000 per annum; of these only 17 per cont. were febrile diseases, whilst 38 per cent. were diseases of the digestive system, chiefly dysentery and diarrhea, and nearly 17 per cent. ophthalmia, which is always so common in Egypt. As for the deaths, there were 172 deaths in the whole force, of which 98 were from battle or accident, leaving only 74 from discase, or a ratio of 5.88 per 1,000 for 87 days, equal to 24.67 expanded to a jear, a rate not much greater than what the Grards showed in London before the Crimean Var. It was even 6 per cent. less than the exceptionally healthy Abyssinian Campaign which had previously stood out as a hggienic model. If to this it be added that, in a country with such an evil reputation for the disease, not one man out of 1,145 cases of ophthalmia lost bis sight, and that there was, for the first time in the history of the world, a cumpaign fought without the occurrence of a single case of so-called hospital disease, pyæmia, hospital gangrene, and the like, I think I may well express my opinion that the Army Medical Officers did their duty, and deserved well of their country, in spite of the unjust obloquy which has lately been heaped apon them, but which time will as certainly remore as it has done in similar cases in times gone by.

In conclusion, I wish to call attention to the difficulties which hygiene has to encounter in time of war. Putting aside the necessary exposure to the vicissitudes of climate and weather, the want of food that may occur, or the insufficient character of the rations, and various other ledentia, more or less inseparable from a state of war, there is one very serious diffeulty, and that is the great compression of popalation. The most open order of camps in war-time gires a much smaller space per lead than the most crowded conditions in civil life, and camps may be so compressed as to give only 8 squaro yards or less per head. Each person in London has about 96 square yards, in Paris about the half of this, but to give even the Paris allowance would spread an army over a space too great for military purposes. When, in addition to this, drainare has to be extemporized, and the ground covered with latrines, and when pure and wholesome water is a difficulty, it is little wonder that disease breaks out. It is to those circumstances that the typhoid ferer, which has characterized our campaigns in Sonth Africa and Egspt, must be attributed in great 
measure, as well as in some degree the dysentery. I would suggest, ander such circumstances, that fire should be brought more into requisition and everything be burnt that is combustible. It is a standing rule in camp to burn all rubbish, but I roold suggest that all excreta should be mixed with combustibles, such as straw or sawdust, if procurable, and burnt. It would eren repay the trouble to carry petroleum for this purpose. Similarly, I would, as far as possible, cremate all bodies, which can be done by means of ambulatory furnaces. Could those precautions be carricd out, and all water that affords the least suspicion boiled, we should go a long way towards getting rid of some of the most fatal but preventible diseases which attacks troops in the field. If cholera or yellow ferer inraded a force, I should advise the burning process to be rigidly applied to all stools and romit, and none but distilled water to be issued to the troops, if it could be managed.

Although we are far from baving solred all the questions of hygricne or of the causation of disease, there are sufticient principles established to enable us to say that, if the rules already recognized were strictly carried out, we should be able to cope successfully with preventible disease, eren under the difficulties and impediments which are inseparable from active service in the field.

Mr. Edwix Chabwick; C.B.: May I be permitted as an old Sanitary Commissioner to express my rerg great pleusure at the paper that has just been read, in the extent to which it displays the operation of sanitation in the Army during peace? The progress I think may bo marked in this way. IIere amongst the Guards, some twenty sears ago, the death-rate was 20 per $1, \mathrm{C} 00$. The death-rate amongst cirilians of adults of the wage class $I$ take is, in or about Westminster, not less than 12 in 1,000. If a man of that class had formerly enlisted in the Guards it would hare been at the expense of nearly a double deall-rate, but if he enlists now when the death-rate is only 6 in 1,000 , or about onc-third of what it is in some years, he will gain proportionately in the duration of his life and working ability. I think cren including war risks lie would be safer than if he remained a cirilin. When these conditions (which admit of yet further improrements) are knomn it should conduce to the abatement of the present rery serious diffieulty of recruitment. With a completed Eanitary serrice and complete sanitation, men of the rage classes, instead of haring to encounter an insurable large loss of life, mas hare an insurable small one, with the war risks included. It would add to the interest of the subject if the comparatire progress that is making in eanitation in tho Armies of France and Germany could be got and stated in detail. But erergwhere in ciril life, as well as in the Army, the obstacles to sanitary progress are the alleged expense of the measures to effect it. Now this great principle should be known, that a hearily death-rated ciril population, as also a hearily death-rated army, is an expensire population and an expensire army. I hare no doubt if you estimate the expense of the present conditions in India, where the moncy saring has been during the last decade upwards of fire millions, it will be found to be an cconomy upon the expenses. Tako an example from ciril life. In some of the slums the death-rates are as much as 40 per 1,000 as compared to 15 per 1,000 , to which it has been now brought in the model dwellings and in a number of urban districts. The death-rate of 40 per 1,000 will include 25 funerals per annum in excess, and bejond that, some twesty times that number of sickness, and also of disablement of more thun one-fifth of the cases of adults, and a loss of working ability for sereral wecks. When all these expenses which must be incurred are added up, it is clear that well conducted sanitary operations may be conducted simply for the saring of money quite apart from the saving of pain and misers, and of 
premature mortality. What I hare said as to the Army is on the progress of eanitation during peace. I should make a large reserre, especially from the last example, as to any great progress made as displayed in the recent war. There is one point I must take a little exception to, and that is, I cannot concur in the results stated with respect to the recent war in Egspt; and I think Dr. de Chaumont has made a mistake which he ought to correct, namely, in spreading the death-rate for eighty dars orer the whole year. We have at present an Intelligence Department for getting out conlitions that will hare to be encountered in war. My opinion is we ought to have an Intelligence Department for ascertaining what is the condition of things that will hare to be encountered in other countries, and which mas cause us three or four times as great a loss as the loss by the sword. If for instance there had been an early sanitary reconnaiszance into Errpt, there would hare been-sercral days before the landing, or inmediately upon the landing of the force-a knowledge of the unsanitary conditions to be dealt with, and action could have been taken accordingly, and I beliere if there had been a good sanitary reconnaissance you rould hare found that there were camping grounds woll known to all the natires, well known to the doctors of the place as being dangerous to encanp upon, while others close by would lare been safe. Such an omission may not hare been due to any fault of the General; it might have arisen from the hurry of the war. Lord Wolscley has in his excellent manual given very good instructions as to what slould be done on those occasions, that he would require from the sanitary officers an esamination and a report on the condition of the camping ground, and upon such report he would be gorerned as to the stations that he continued to occups. I might illustrate the fatal mistakes committed with the first army in the Crimen, and how they were corrected by the work of the Special Sanitary Commission for the sccond army, and how, so far as we at present know, the losses that have occurred in the last, fortunately short, campaign, miglit lare been prerented. Howerer that may be, this paper showing the progress that has been made bj sanitation during peace, and the yet further progress that may be expected, I deem a good contribution to sanilary science, and I think thanks are due to my colleague of the Sanitary Institute for the pains be lias taken, and I only hope that he mas hare strength and power to continue them for a long time to come.

General R. ILACLAGAx, R.E. : There are one or tro points in the paper to which we hare listened on which I desire to make a few remarks. Some rery important obsorrations hare been made on wlat is known to be a rers important matiter, the "ccommorlation of our soldiers in barracks. Tith reference to the amount of cubic spaco allutted to each man, there are circumstances apparently in which great deriations from the rules on this subject are yet not attended with any hurtful consequence. An adrantige seems to be gained when the number of men accommo. dated within one room is small, though they may not have the amount of floor area and cubic space usualls considered necessary. In India, on certain occasions when men liare of necessity been accommodated for a time in much smaller buildings than are usually allotted to them, but in which only three or four were in one room, it was remarkable how healthy thiese men were. In one instance at a station on the frontiers of the Punjaub when an addition had to be made to the number of Furopean troops, and the accommodation was insufficient, a number of the men were for a time put into raulted apartments under the barracks originally intended for stores. It was meant to be a rery temporary arrangement, the rooms being considered quite unsuited for the accommodation of Europeans. Homerer, circum. stances required them to be kept there for a considerable length of time, nnd as a matter of fact, these men so accommodaticd were among the most healilyy of the European soldiers in that proxince. It would be a rery rash thing to generalize from such a fact, and infer that this was a good mode of accommodating soldiers; all wo can say is that there must lase been some circumstanee there which prerented any eril effect from the reduced space arailable. One reason, no doubt, was that these apartments were mucli moro protected from the sun by dar and from the cold by night. Next, with regard to the lecturer's ohscrrations rerarding the effect on the health of soldiers in India from being confined within their barracks during the long hot dar, while other persons who are not so confined and hare much out-of-toor 
duty enjos better health - (ciril Officers, military Oficers, engineers, and others)it should be noticed that for the most part these cirilians, Ofincers, and others who hare certainly a great amount of out-door occupation hare that occupation just as the soldier has, ehiefly in the early morning and in the erening. Ciril Offecrs are generally as much within doors during the daj as soldiers, and often under much more unfarourable circumstances for many hours together in crowded court rooms ; and though the Officerz, ciril and military, mas often hare occasion to be much in the open air, eren in hot weather, their families are always as-much confined to the house as the European soldiers to their barracks. Their better general health is due probably to their haring better general accommodation, better food, plenty of air in their houses, and other adrantages; but not to their being less coufined to the house than soldiers. On the ambject of the amount of cubic spacc, I think the lecturer observed that 3,600 cubic feet per man was just equiralent to one cubic foot per second. This seems to imply that the whole of the air is renewed in the course of an hour. That I think can scarcels be assumed. 'There was one rers interesting part of the lecture on the connection of work of rarious kinds with the health of the troops; and notice was taken of the comparatire healthiness of caralry, artillery, and infantry. It would have been of great interest if the comparison had included the enginecr soldiers, the sappers and mincrs, who are generally so much more emplored than most of the other men on out-door'work. When infantry soldiers have been emplosed on publin trorks, as thes hare frequently been in India on hill roads, their health has been particularly good. The employment has been no less adrantageous than the hill climate. Mlay I be allowed, with reference to the remarks of the last speaker, to supplement what I said just now on this subject? 'There is no question that the occupation of the mind of the soldier, besides being profitable in itself, is one of the most important aids to bodily health. In-India, a great deal has been done of late years towards proridmg this in an adrantagcous way. The men do not now usually oecupy the same rooms during the day and during the night. The newer barracks are double-storesed. In the lower storess are the rccreatiou rooms and mess rooms, and rooms in which they carry on rarious oceupations during the day. The upper storeys are the sleeping rooms. In trying times of sickness also, the occupation of the inind is most important. On the occasion of a sudden outbreak of cholera among our troops in India, it is found best to more the men at once out into camp) or temporary shelter, even at a season when they would never, under ordinary cireumstanees, be put under canras, and the immediate occupation of the mind in making the move, the roughing it, the inconrenience serres perhaps as much as the mere change of place and air to fend off the attack of that terrible disease. We hare reason to be glad that this subject has been brought before us so fully as it has in the lecture to-day. It is a subject not second in importance to any of those dis. cussed within these walls, affecting so directly and closely as it does the efieiency of our Army.

Major-General Duxxe: Following the OPeer who has just spoken with regard to the troops in India and their being kept all day long in their barrack rooms, I may mention that at places like Fort William, in Calcuita, it would be absolutely impossible to allow joung troops anj frecdom, comparatively, of going about in the day in hot weather. MIr own experience of India as a young man was that a great deal of the sickness amongst infantry when they are first put into barracks in India arose from the fact that thes lad a large amount of meat and used to drink a large quantity of beer, and that thes had nothing in the world from morning to night to amuse their minds. They had no occupation from breakfast time in the morning until 5 or 6 o'clock in the erening. I hare no doubt the Officer who last addressed us will corroborate this, that the infantry soldier dic nothing but eat a big dinner and then tuck himself under his inosquito curtains and snooze away half the afternoon. I think if more indoor recrcation could be fourd for the men, great improrement would result. No doubt, of late years there has been more oceupation found for them. But 1 think they should not be allored to go about in the open in the heat of the day. Soldiers could not be trusted-they would hare sunstroke orer and orer again; but to amuse them and gire them occupation in barracks is the best thing for them. ' No doubt why the Enginecrs are a more licalthy body of men in India than the infantry is for the 
simple reason that their minds are more occupied and there is more work for them to do during the day.

Colonel BATLIs, Q.C.: I renturo, not being msself one of the regular army, to male a few obserrations, but with considerable diffdence. Most useful practical suggestions hare been made, and they are founded upon the best of statisties. Are these uscful measures of prerention to go on? We trust that this lecture will not bo withont its fruits. We are sorry to seo so fom attending a lecture of such general importance not only to the $A \mathrm{rm} 5$ but to erery one. I can only account for it in this way: if you talk of measures of prerention to persons, they are always somelow or other loth to follow them; it is only when something orertakes them with great severity that the 5 will attempt to do ansthing in the future to prevent its recurrence. And I am not clear but this is the causc of it: it is found that the more successful measures of prerention are somehow or other the less do they appear to be needed, and the less are they followed up by further reform. People do not look at resultis sufficiently; they say the world is working rery well, but they do not lnok sufficientls at the cause of its working. Now we all allow that a great deal of the present improred sanitary state of the Army is due to precautions which hare been taken; aud we onlJ hope that the effect of this lecture will be to follow up what has been done and to let these practieal suggestions be carried out. The lecturer attributes a great deal of mischief to the tight dress worn in the Army. We know that with ladies appearance gocs a rery great was, and so it secms to do in military matters. I hope, howerer, that some practical result will come from this lecture, and that it will be seen that the first consideration is to make the Army healthy and thereby effective. We must all also admit that the occupation of the mind lias a great deal to do with the health of the body. I hope, therefore, we shall look after the mental occupation of the Army. If whilst doing that, Tre gire the men as much opportunity as possible for following active and healthy pursuits, physical and mental, we shall find less discase and they will not have recourse to those things which so often bring on disease. The suggestions as to the selection of camp sites, and taking precautions beforehand, I think are most important, and I renture to hope they will be carried out.

Dr. DE CIIExONT : I should wish to say a few words in reply to some of the remarks that have been made. In the first place with regard to what has fallen from my friend IIr. Chadwick. on the subject of the statistic of the Egsptian compaign, ho must allow me to correct him, for he has not quite apprehended what I hare stated. I stated that the total number of deaths from cliseaso during the period of 87 dass mas 74 out of a total force of 13,000 . Now if that is taken as a ratio for those 87 days alone, it gires a ratio of $5 \cdot 88$ per 1,000 . But if I expand that ratio to a wholo year, that would come to 320 deaths, which upon the 13,000 gires the ratio which I gare of $2.4 \cdot 67$ per 1,000 , and $I$ do not think it would be possible to make it any more. I expanded it for a whole year by multiplying the cleaths in the ratio of 365 divided by 87 , and that gires $2.1 \cdot 67$ per 1,000 , which I think is an extremely small ratio for a campaign fought under such rery adrerse circumstanecs. With regard to the remarks by Geueral Maclagan and also MajorGencral Dunne, I quite agree that a great deal must be lail to the occupation of the mind of the soldier, and there are no doubt manr causes of unlealthiness other than mere confinement to barracks, but speaking of the time of my own experience in India, which $I$ am sorry to say is nearly a quarter of a century ago, there is no doubt at that time men were confined to barracks the whole das and the air mas extremely foul, and I think I was able to trace the bad effects of it in the general health of the men. Of course if the men are sent to another room to pass the day it is a good thing, but the main objection $I$ mas bringing forward was that the men were confined to barracks in an improperly rentilated air space, which theJ were again compelled to occups during the night, and I still maintain at that time the remedy was worse than the disease. The men mould not hare suffered so much if they had been allowed the utmost freedom in the open air. Of course if it is found that men cannot be trusted to protect themselres from the sun there is no doubt precautions must be taken to protect them, but it must be done in an intelligent way, -in such a way as shall be an adrantage to the soldier and not a disadrantage. There mas one remarl that General JIaclagan nade with regard to the 
amount of fresh air which I suggest as being necessary. IIe said that this would demand that the whole air of the barrack should be changed ererg hour. But we not only demand that, we demand three times that. Fren in the present dar the limited demand of the Barrack Commission is that the air shall be clanged in erery room at least trice in the hour in order to gire a man 1,200 cubic feet. He gets 600 cubic feet of space, and if he ought to have 1,200 cubic feet of air the air must bo changed twice in the hour, but we say the air may be changed three times in the hour. I think it is quite possible we may get increased space and 3,600 cubic fect per hour for the soldier by-and-bye. And this brings mo to another point that was referred to also by General Maclagan, namely, that the case has occurred more than once where men hare been placed urder apparently adrerse circumstances, as for instance where they hare not been allotfed the full amount of cubic space, and yet hare maintained rers good health. I do not dens that at all; I think it is quite likely, but other circumstances must come in, and $I$ would here point out That is rery often forgotton, or not understood, that cubic space itself is no substitute for rentilation, that is to say what we want is that men should? hare fresh air delirered to them; it must be delirered in such a way as will be without injury to them in the was of chilling them, or being otherriso unpleasant, but they must bare a certain amount of fresh air, and it is perfectly immaterial how it is giren, but under no circumstances can cubic space erer be permitted to take the place of fresin air. Many men think if you put the men in a large room, that is all that is requirel, but if you occups the room for a few hours shut up, it will be poisoned just as mueh with 10,000 cubic fect as if it were 100. If it is impossible to deliver a sufficient amount of fresh air and a man occupics only 600 feet of space, it is obrious you must gire him more, but this is merely with reference to the practicability of a continuous delirers of air. A man may keep his health perfectly if he is only occupsing 100 square feet of space if he could be prosided with a sullicient number of cubic feet per hour, or he miglst attach a respiratory apparatus to his mouth and nostrils, and in the foulest atmosphere jou might kecp bim alire and healthy by bringing fresh air to him and taking away the foul air. The cubic space is quite a side issue with regard to the actual rentilation, so that in these cases where men hare been apparently crowded together, in all likelihood the fact has been that there were large openings through which fresh air could rery casily be brought in. JIen are very often crowded together in the open air, and if the crowding is not too excessire they may keep their health. I might hare added, as has been suggested, the statisties of other armies, but it would have rather prolonged the lecture. I may merely mention that the experience of our orn Army is by no means unique, and that if we study the results obtained in the French, German, and dustrian drmics, we find that the same conditions produce the same crils, and the same remedies hare produced similar results. The death.rate in the French drmy has been reduced at least one-half both in France and in the Colonial serrice. In Germany and Austria the same thing has occurred; with improved measures of sanitation, especially improring rentilation and serer arrangements, they hare got rid of a rery large amount of discase, but there still remains the instructive fact that in the forcign Armies there exists a rery large amount of precentible discaso that tre are gradually getting rid of. For instanee, typhoid ferer is only too common among the French soldiers. Anjone who has experience of the ahominablo way in which the excreta or sewage is dealt with in France will easily understand why this should be, and why such discascs as typhoid, diphtheria, \&c., should mge in foreign cities when they are a rery small item in the death-rate here. I will just remark with regard to this, the difference between what we do in this country and what is done abroad. My friend Dr. Ballin, Professor of IIygiène at tho Tal de Grâce, told me the conclusion he bad come to was this: "Your strects" ho said, "in your citics, particularly London, are filthy dirty, and jour ecrers aro simply abominable, but your houses are admirably clean, and you bare a copious supply of mater, and therefore you are healthy. In Paris," he said, " our streets are beautifully clean, you might hare a dinner party in the sewers; but we keep all the filth in our houses and the water supply is totally insufficient : the result is we are decimated with discasc. After all," ho sajs, "Jour system is the best" and I think me may say so too. 
The Charrasas: I cannot pass orer the discussion which has taten place on this able paper of Dr. do Chaumont's without adrerting to a subject with which, howerer, he does not deal at all, and that is camping. Mr. Chadrick bas stated that there is great fiult to bo found with camping ground in Eggpt. I need hardly tell $\mathrm{my}$ audience here that an army in the field cannot al wajs choose its camping ground; it must camp where its General wants it. I must say, howerer, from what I hare heard both here and elsewhere regarding the sclection of the camping ground at Cairo, that the only camping grounds that could have been occupied were those which were occupicd, and that the authorities who determined to camp the troops in the place where they mere encamped at Cairo had the rery best information on the subject, namoly, the adrice of the Khedire of Egspt and his staff. I feel it necessary to say this in justice to the advisers of the General and to the General who commanded. the Army in Egypt, than whom I fancy there is no mure competent sanitary or strate gic General perhaps in our Army. I think it right also to say that the drmy was well adrized by a rery competent sanitary Officer whio was on the staff of the Quartermaster-General in Egypt. With regard to the paper, I have one single remark to make, and that is that the whole of this admirable nurratire, based as it is on statistics which do not admit of being disputed, shows if enytling can show clearly and very logically too, that we are certainly on the right roal to sccure for our Army the best possible health consistent with the conditions under which soldiers must serre, and, therefore, I hope that the result of this adunirable lecture, containing as it does information on the subject giren to $u s$ in prerious jears by the same author, will be that the Gorernment will be stimulated to continue those sanitary efforts which have done so much for the health of the Army, and for the saring of life in tho Army, and that thus the ranks of the Army will become more and more popular and its efficiency more and more marked. With these rery brief obserrations I would ask you to give our distinguished lecturer a sery warm rote of thanks. Although our audience here is a limited one, jet it is a rerg influential one, and when it is borne in mind that this lecture through the medium thruugh which it will be published will address itself to almost erery Office in the British or Indian Armies, I hare no doubt that sou will think that the hour deroted to the consideration of this subject this afternoon bas been e stremels well spent. 